\title{
Benthic macroinvertebrates as bioindicators of water quality in Billings Reservoir fishing sites (SP, Brazil)
}

\author{
Macroinvertebrados bentônicos como bioindicadores da qualidade da água em \\ locais de pesca do reservatório Billings (SP, Brasil)
}

\section{José Ricardo Baroldi Ciqueto Gargiulo ${ }^{1 *}$, Cacilda Thais Janson Mercante ${ }^{1}$, Ana Lucia Brandimarte ${ }^{2}$ and Luciana Carvalho Bezerra de Menezes ${ }^{1}$}

\begin{abstract}
${ }^{1}$ Instituto de Pesca do Estado de Sáo Paulo - IP, Secretaria da Agricultura e Abastecimento do Estado de São Paulo - SAA, Agência Paulista de Tecnologia do Agronegócio - APTA, Avenida Francisco Matarazzo, 455, Barra Funda, CEP 05001-900, São Paulo, SP, Brazil

${ }^{2}$ Departamento de Ecologia, Instituto de Biociências, Universidade de São Paulo - USP, Rua do Matáo, 321, travessa 14, Cidade Universitária, CEP 05508-090, São Paulo, SP, Brazil *e-mail: ricardogargiulo@gmail.com
\end{abstract}

Cite as: Gargiulo, J.R.B.C. et al. Benthic macroinvertebrates as bioindicators of water quality in Billings Reservoir fishing sites (SP, Brazil). Acta Limnologica Brasiliensia, 2016, vol. 28, e17.

Abastract: Aim: The Billings Reservoir is the largest reservoir in the metropolitan region of São Paulo and has multiple uses, including artisanal fishing. Its surroundings present intense occupation, resulting in various environmental impacts. Although the water is degraded, affecting the composition and quality of the fish, this reservoir supports artisanal fishermen who survive through this activity. This study aimed to analyze the water quality in the main sites of artisanal fishing activity, with an emphasis on the benthic community as a bioindicator. Methods: Three sampling sites were selected, in which water and zoobenthos samples were collected monthly from April 2012 to March 2013. Water analyses consisted of the determination of $\mathrm{pH}$, temperature, conductivity, turbidity, total dissolved solids, dissolved oxygen, total nitrogen, total phosphorus, and trophic state as well as a principal components analysis. The zoobenthos analysis consisted of determining the relative abundance and total density of taxa, the Shannon-Weaver diversity index, taxa richness, uniformity, Simpson's dominance index, and the benthic community index and conducting a canonical correspondence analysis. The non-parametric Kruskal-Wallis test followed by the Student-Newman-Keuls test were used to investigate the existence of significant differences in the abiotic and biotic variables among the sites. Results: The studied sites showed a high degree of eutrophication, with nitrogen and phosphorus totals levels above the limits defined by current Brazilian legislation. Taquacetuba (P1) showed the best environmental conditions for the development of fishing activity, with the presence of sensitive organisms (Polymitarcyidae) and higher levels of dissolved oxygen. Alvarenga (P2) had the worst water quality, with a predominance of tolerant organisms (Oligochaeta) and lower levels of dissolved oxygen. Conclusion: In conclusion, the benthic community in association with abiotic metrics proved to be a useful tool as a bioindicator of environmental conditions, indicating that fishing activity at Alvarenga is not recommended due to the degradation of water quality.

Keywords: zoobenthos; environmental impact; eutrophication; artisanal fisheries.

Resumo: Objetivo: O Reservatório Billings é o maior reservatório da Região Metropolitana de Sáo Paulo, com usos múltiplos, incluindo a pesca artesanal. Seu entorno apresenta intensa ocupação, estando sujeito aos mais diversos impactos ambientais. Apesar de a água apresentar-se degradada, 
comprometendo a composiçáo e a qualidade do pescado, este reservatório conta com a presença de pescadores artesanais que sobrevivem desta atividade. $\mathrm{O}$ presente estudo teve como objetivo analisar a qualidade da água nos principais locais de atividade de pesca artesanal, com ênfase na comunidade bentônica como bioindicadora. Métodos: Foram selecionados três pontos amostrais, nos quais amostras de água e zoobentos foram coletadas mensalmente de Abril de 2012 a Março de 2013. A Análise da água consistiu de $\mathrm{pH}$, temperatura, condutividade elétrica, turbidez, sólidos totais dissolvidos, oxigênio dissolvido, nitrogênio total e fósforo total e também de Análise de Componentes Principais e estado trófico. A Análise do zoobentos consistiu de abundância relativa e densidade total de táxons, diversidade de Shannon-Weaver, riqueza de táxons, uniformidade, dominância de Simpson e também de Análise de Correspondência Canônica e Índice de Comunidade Bentônica. Os testes náo paramétricos de Kruskal-Wallis seguido por Student-Newman-Keuls foram utilizados para investigar a existência de diferenças significativas nas variáveis bióticas e abióticas entre os locais. Resultados: Os locais estudados apresentaram alto grau de eutrofização com níveis de nitrogênio e fósforo totais acima dos limites da legislação vigente no Brasil. Taquacetuba (P1) apresentou as melhores condiçôes ambientais para o desenvolvimento da atividade da pesca com presença de organismos sensíveis (Polymitarcyidae) e maiores teores de oxigênio dissolvido. Alvarenga (P2) apresentou a pior qualidade da água, com predomínio de organismos tolerantes (Oligochaeta) e baixos teores de oxigênio dissolvido. Conclusáo: Concluiu-se que a comunidade bentônica, em conjunto com variáveis abióticas, foi indicadora eficaz das condiçóes ambientais, sinalizando que a atividade pesqueira em Alvarenga não é recomendada em função da acentuada degradação da qualidade da água.

Palavras-chave: zoobentos; impacto ambiental; eutrofização; pesca artesanal.

\section{Introduction}

The Billings Reservoir is located in the basin of the Tiete River in São Paulo State (Brazil), covering the entirety of six municipalities in the metropolitan region of São Paulo (Diadema, Ribeirão Pires, Rio Grande da Serra, Santo André, São Bernardo and São Paulo). This is the largest water reservoir in the region, with an area of $127 \times 10^{6} \mathrm{~m}^{2}$ and a maximum depth of $19 \mathrm{~m}$. This reservoir shows a history of conflict among its multiple uses in recreation, the professional activity of artisanal fishing, power generation, effluent dilution, flood control and water supply (Cardoso-Silva et al., 2014). Though the water is degraded, affecting the composition and quality of the fish, there are many artisanal fishermen who survive through fishing. According to Alves da Silva et al. (2009) and Castro et al. (2009), between 2005 and 2007 at Billings Reservoir, approximately 100 families lived exclusively on resources from artisanal fisheries, but this number has been decreasing in recent years, which has been attributed principally to the pollution in the reservoir. These authors showed that the most representative species were acará (42.9\%) (Geophagus brasiliensis, Quoy \& Gaimard, 1824), tilapia (25.2\%) (especially Oreochromis niloticus, Linnaeus, 1758, but also Tilapia rendalli, Boulenger, 1897) and lambari (16.3\%) (Astyanax spp., especially Astyanax eigenmanniorum, Cope, 1894 and Astyanax scabripinnis, Jenyns, 1842). Although the environment surrounding the reservoir contains areas with good environmental preservation, many regions show urban development and agriculture, which contributes to its degradation, especially by sewage and industrial and agricultural waste. Another environmental contamination factor is the pumping of water from the Pinheiros River into the Billings Reservoir; this transposition occurs for flood control during the rainy season (EMAE, 2014), and the Pinheiros River has a high degree of eutrophication and environmental stress.

The state environmental agency - CETESB (Companhia Ambiental do Estado de São Paulo), through their annual reports, classifies the Billings Reservoir as eutrophic to hypereutrophic, depending on the analyzed compartment (CETESB, 2013). In this context, the use of this reservoir for artisanal fishing is worrisome, and the water quality should be assessed properly.

The methods traditionally used to assess the water quality of aquatic ecosystems based on physical and chemical parameters are considered inefficient (Buss et al., 2008). Bioassessment is widely used in the monitoring and management of environmental quality and the integrity of aquatic ecosystems, complementing traditional physical and chemical methods (Karr, 1999; Linke et al., 2005). Benthic macroinvertebrates are widely employed in impact assessments and are recommended for environmental monitoring (Fonseca-Gessner and Guereschi, 2000), as they possess several features that make them outstanding biological indicators (Hellawell, 1986; Rosenberg \& Resh, 1993).

The arguments for the use of benthic macroinvertebrates as a biological tool in biomonitoring programs are numerous. These include the facts that they are cosmopolitan 
and abundant animals, most have well-known ecological characteristics, they are sessile or have limited mobility and therefore are representative of local conditions, and they have the advantage of characterizing the water quality not only at the moment of sampling but also by reflecting their position over a longer period of time (Moreno \& Callisto, 2005).

The analysis of the structure and distribution of the benthic community is an important ecological tool for describing spatial and temporal changes (Callisto et al., 1998; Leal \& Esteves, 1999). According to CETESB (2013), by inhabiting the sediment and being sensitive to disturbance in the aquatic environment, the benthic community is considered a good indicator of the ecological quality of water bodies. Some studies (Pamplin et al., 2006; Carew et al., 2007; Jorcin \& Nogueira, 2008; Buss \& Vitorino, 2010; Cortelezzi et al., 2011; Miserendino et al., 2011) have improved the knowledge of the bio-indicator potential of benthic macroinvertebrates.

The main objective of this study was to use the benthic macroinvertebrate community as a tool in the assessment of the water quality at fishing sites in Billings Reservoir (SP).

\section{Materials and Methods}

\subsection{Study area}

The Billings Reservoir has an area of approximately $120 \mathrm{~km}^{2}$ and has a complex and dendritic format, with a long and narrow central body with eight branches. It has a maximum depth of approximately 18 meters, an average volume of $646,841 \times 10^{6} \mathrm{~m}^{3}$, an average flow of $8.75 \mathrm{~m}^{3} \cdot \mathrm{s}^{-1}$ and an approximate water retention time of 720 days (CETESB, 2012, 2013).

The sampling sites (Figure 1) were selected in the areas with the highest intensity of fishing activity. Information about these areas was obtained from the community of traditional fishermen through reports obtained during meetings at Capatazia Z1, Sáo Bernardo do Campo, and data collected by Alves da Silva et al. (2009). According to the Brazilian legislation of São Paulo State (ALESP, 1977 decree \#10775) these sites are classified as freshwater of class of use 2, which indicates they are used for fishing or the growing of organisms for intensive consumption purposes.

- Sampling site 1 - P1 (S 2349'54.0"; W 46.38'26.9") is located in the Taquacetuba branch close to the central body of the reservoir, which is an area with good preservation of the Atlantic Forest in its surroundings along with some agricultural areas because the forming region of the Taquacetuba River occurs in a location with several protected areas. Water collection for transposition into the Guarapiranga Reservoir for public supply purposes occurs in the Taquacetuba branch.

- Sampling site 2 - P2 (S 2346'01.0”; W 46 $\left.37^{\prime} 37.7^{\prime \prime}\right)$ is located in the Alvarenga region, an area with the total removal of the Atlantic Forest and great urbanization in its surroundings. This area was chosen because, according to the fishermen, the fish obtained there had unpleasant odor and taste. Thus, it would be possible to infer the effects of the interference of water quality on fish quality. Among the sampling sites, P2 is the closest to the pumping area of the water from the Pinheiros River.

- Sampling site 3 - P3 (S 2348'53.2”; W 4632'94.7”) is located close to Biguás Island, which is located in the central body of the reservoir close to the fishing colony and the João Basso ferryboat and is an area with Atlantic Forest and low urbanization in its surroundings

\subsection{Sampling and data analysis}

From April 2012 to March 2013, water and sediment (zoobenthos) samples were collected monthly from three sampling sites located at least 10 meters from the banks. The water was collected 0.5 meters from the bottom using Van Dorn bottles for the analysis of total nitrogen (TN) and total phosphorus (TP) following the methods described by Valderrama (1981), Mackereth et al. (1978) and Strickland \& Parsons (1960). In the field, the abiotic variables $\mathrm{pH}$, water temperature (Temp), electrical conductivity (Cond), turbidity (Turb), total dissolved solids (TDS) and dissolved oxygen (DO) were measured with a Horiba U-22 multi-probe at 0.5 meters from the bottom.

A principal component analysis (PCA) was used to verify the ordering of the sampling sites in relation to the intensity of the association among the abiotic variables. To assess the water quality related to nutrient enrichment, the Lamparelli's trophic state index (TSI) for the total phosphorus concentration was used according CETESB (2015).

Macroinvertebrates were sampled by collecting three samples of sediment with an Ekman-Birge 


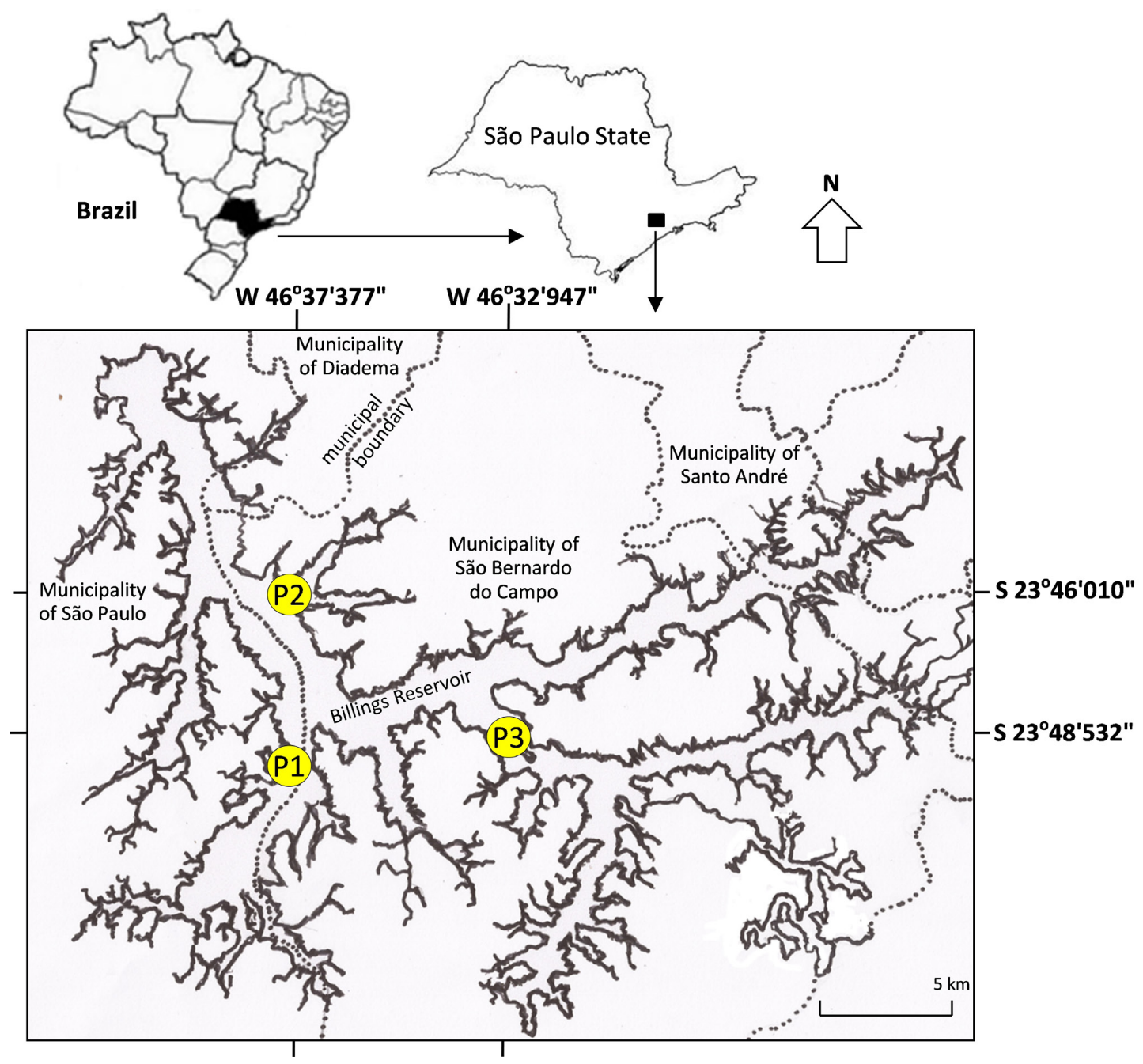

Figure 1. Study area and approximate location of sampling sites at Billings Reservoir (Southeastern region of Brazil, Sáo Paulo State): P1 - Taquacetuba, P2 - Alvarenga and P3 - Biguás Island (dotted lines - municipal boundaries).

grab $\left(225 \mathrm{~cm}^{2}\right)$ at each sampling site (Pérez, 1996). The samples were washed over a $250 \mu \mathrm{m}$ mesh and floated following the methods described by Brandimarte \& Anaya (1998). The taxonomic identification of organisms was based on Macan (1975), Pennak (1991), Merritt \& Cummins (1995), Trivinho-Strixino \& Strixino (1995) and Pérez (1996).

The benthic community was analyzed by calculating the relative abundance (\%), density of organisms $\left(\right.$ org $\cdot \mathrm{m}^{-2}$ ), Shannon-Weaver diversity index (H'), taxa richness $(\mathrm{S})$, uniformity (U') and Simpson's dominance index (C), according to Elliott (1977), Ricklefs (2011) and Begon et al. (2007). The multimetric benthic community index (BCI) was also calculated from the diversity and richness (CETESB, 2013).
The results of the analyses of the abiotic and biotic variables are presented with box-and-whiskers plots, in which the lower and upper limits of the box correspond to the 25th and 75th percentiles, respectively, the whiskers correspond to the minimum and the maximum values, and the center line of the distribution corresponds to the median. The non-parametric Kruskal-Wallis test $(\mathrm{H})$ followed by a Student-Newman-Keuls (SNK) test were used to investigate the existence of significant differences in the abiotic and biotic variables among the sites. A canonical correspondence analysis (CCA) was used to verify the ordering of the sampling sites in relation to the intensity of the association among the abiotic variables. The statistical analyzes followed Hair et al. (2009), Sokal \& Rohlf (2009) and Zar (2010). All analyses 
were carried out using the routines of the PAST 3.x and BioEstat 5.1 programs.

\section{Results}

\subsection{Spatial variation in abiotic variables}

The box-and-whiskers plots of the abiotic variables (Figure 2) demonstrate that the $\mathrm{pH}$ values were nearly acidic, with variation among the sampling sites of min: 4.9 and max: 6.7. The medians of the $\mathrm{pH}$ values were under the CONAMA (2005) \#357 limit (between 6.0 and 9.0) at all sites (P1: 5.61, P2: 5.59 and P3: 5.59). The highest values of electrical conductivity $\left(343 \mu \mathrm{S} \cdot \mathrm{cm}^{-1}\right)$, turbidity (72.7 NTU), total dissolved solids (223 $\left.\mathrm{mg} \cdot \mathrm{L}^{-1}\right)$, total nitrogen $\left(15.37 \mathrm{mg} \cdot \mathrm{L}^{-1}\right)$ and total phosphorus $\left(0.24 \mathrm{mg} \cdot \mathrm{L}^{-1}\right)$ were observed at $\mathrm{P} 2$. The total nitrogen and total phosphorus at all sites were above the limits according to the CONAMA (2005) \#357 resolution (TN lower than $1.27 \mathrm{mg} \cdot \mathrm{L}^{-1}$ and TP lower than $\left.0.03 \mathrm{mg} \cdot \mathrm{L}^{-1}\right)$. Regarding the dissolved oxygen, the lowest values were observed at P2 (3.2 $\left.\mathrm{mg} \cdot \mathrm{L}^{-1}\right)$, which was the only site with values below the limit of the mentioned resolution (DO not lower than $5 \mathrm{mg} \cdot \mathrm{L}^{-1}$ ). The Kruskal-Wallis test $(\mathrm{H})$ and a posteriori multiple comparisons using the Student-Newman-Keuls test (Table 1) showed significant differences $(p<0.05)$ in electrical conductivity, total phosphorus and dissolved oxygen between P1 and P2 and between P2 and P3, demonstrating that P2 significantly differed from the other sites.

\subsection{Principal Component Analysis (PCA)}

Regarding the PCA (Figure 3), the first two components explain $61.47 \%$ of the total variability in the analyzed data. Table 2 shows the correlation of the variables with the axes. The PCA showed the worst conditions in relation to the water quality at P2. The data cloud for this site was separated from those of the other sites (convex hull), having greater association with electrical conductivity, total nitrogen, total phosphorus and total dissolved solids. On the other hand, sites P1 and P3 showed greater association with DO.
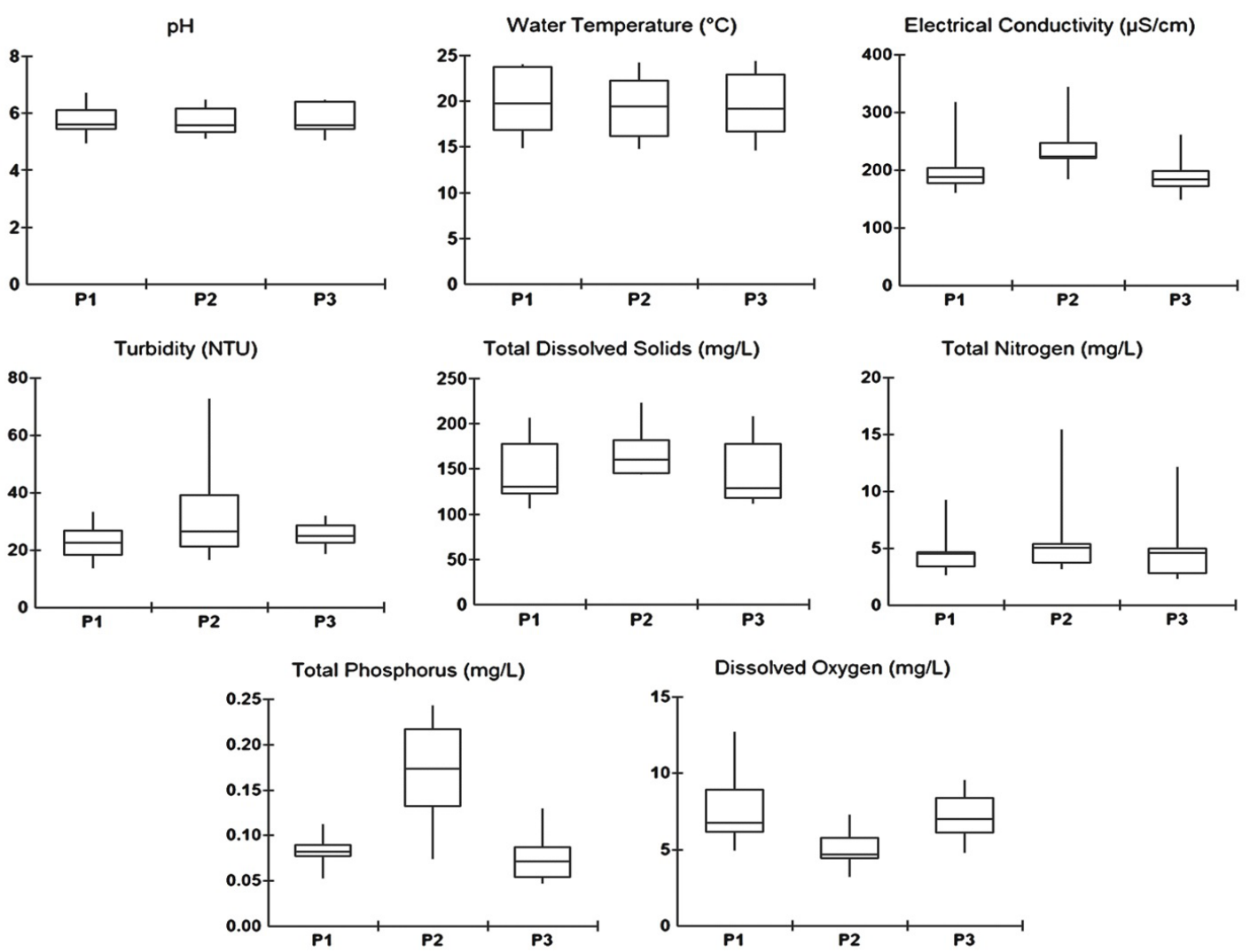

Figure 2. Abiotic variables measured at sampling sites P1 - Taquacetuba, P2 - Alvarenga and P3 - Biguás Island at Billings Reservoir (Brazil, São Paulo State) represented by box-and-whiskers plots where the lower and upper limits of the box correspond to the 25th and 75th percentiles, respectively, the whiskers correspond to the minimum and maximum, and the center line of the distribution corresponds to the median. 


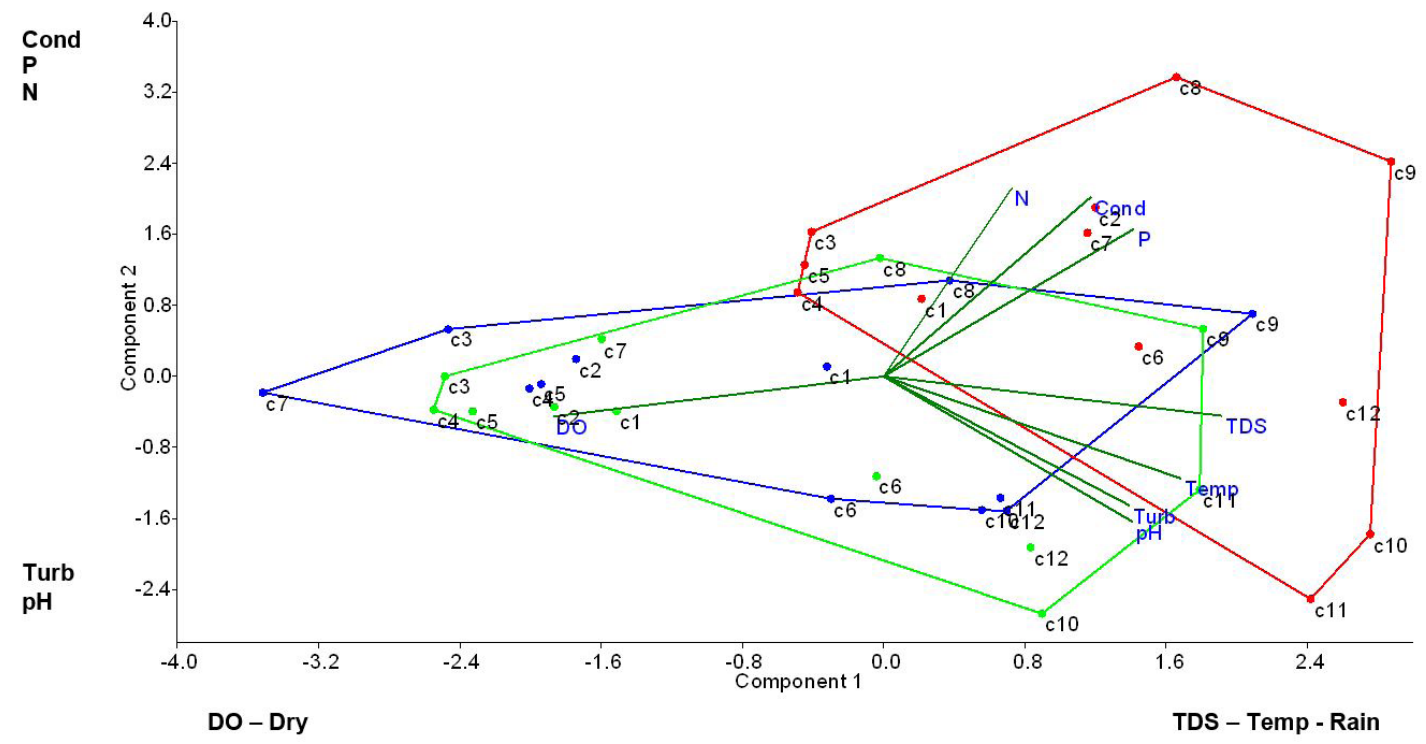

Figure 3. Principal component analysis (PCA) to verify the ordering of the sampling sites in relation to the intensity of the association among the abiotic variables. The numbers represent the collections (samples): C1 (17.04.12), C2 (22.05.12), C3 (26.06.12), C4 (26.06.12), C5 (13.09.12), C6 (24.09.12), C7 (06.11.12), C8 (04.12.12), C9 (18.12.12), C10 (17.01.13), C11 (05.03.13) and C12 (26.03.13). The lines (convex hull) indicate the cloud (data points) represented by the measurements at each site: P1 - Taquacetuba (blue), P2 - Alvarenga (red) and P3 - Biguás Island (green) at Billings Reservoir (Brazil, Sao Paulo State). The vectors (dark green) show the contributions of the variables $\mathrm{pH}$, temperature (Temp), electrical conductivity (Cond), turbidity (Turb), total dissolved solids (TDS), total nitrogen $(\mathrm{N})$, total phosphorus $(\mathrm{P})$ and dissolved oxygen $(\mathrm{DO})$ in the formation of the first two components of the analysis.

Table 1. Results of Kruskal-Wallis test $(\mathrm{H})$ and subsequent Student-Newman-Keuls (SNK) test for abiotic variables among the sampling sites.

\begin{tabular}{|c|c|c|c|c|c|}
\hline & \multicolumn{2}{|c|}{ Kruskal-Wallis } & \multicolumn{3}{|c|}{ Student-Newman-Keuls } \\
\hline & $\mathbf{H}$ & $p$ & $\begin{array}{l}\text { Sampling sites } \\
\text { compared }\end{array}$ & SNK & $p$ \\
\hline $\mathrm{pH}$ & 0.299 & 0.8611 & & & \\
\hline Water Temperture & 0.2662 & 0.8754 & & & \\
\hline \multirow[t]{2}{*}{ Electrical Conductivity } & 13.0938 & $0.0014^{*}$ & $\mathrm{P} 1$ and $\mathrm{P} 2$ & 11.8333 & $0.0059^{*}$ \\
\hline & & & $\mathrm{P} 2$ and $\mathrm{P} 3$ & 14.6667 & $0.0006^{*}$ \\
\hline Turbidity & 2.1495 & 0.3414 & & & \\
\hline Total Dissolved Solids & 4.9165 & 0.0856 & & & \\
\hline Total Nitrogen & 1.8396 & 0.3986 & & & \\
\hline \multirow[t]{2}{*}{ Total Phosphorus } & 18.8996 & $0.0001^{*}$ & $\mathrm{P} 1$ and $\mathrm{P} 2$ & 14.2917 & $0.0009^{*}$ \\
\hline & & & $\mathrm{P} 2$ and $\mathrm{P} 3$ & 17.5833 & $<0.0001^{*}$ \\
\hline \multirow[t]{2}{*}{ Dissolved Oxygen } & 12.8984 & $0.0016^{*}$ & $\mathrm{P} 1$ and $\mathrm{P} 2$ & 13.4167 & $0.0018^{*}$ \\
\hline & & & $\mathrm{P} 2$ and $\mathrm{P} 3$ & 13.3333 & $0.0019^{*}$ \\
\hline
\end{tabular}

P1 - Taquacetuba, P2 - Alvarenga and P3 - Biguás Island at Billings Reservoir (Brazil, Sáo Paulo State), where ${ }^{*}$ indicates significant difference $(p<0.05)$.

\subsection{Trophic state}

The analysis of the trophic state according to CETESB (2015) (Table 3) using the total phosphorus concentrations showed eutrophic conditions at P1 $\left(82 \mathrm{mg} \cdot \mathrm{m}^{-3}\right)$ and P3 $\left(71 \mathrm{mg} \cdot \mathrm{m}^{-3}\right)$ and supereutrophic conditions at P2 $\left(167 \mathrm{mg} \cdot \mathrm{m}^{-3}\right)$. However, the calculation of the trophic state index (TSI) indicated hypereutrophic conditions at all 
Table 2. Correlation of abiotic variables with the axes (components) of principal component analysis (PCA) for the variables analyzed for the sampling sites at Billings Reservoir (Brazil, São Paulo State).

\begin{tabular}{lcccc}
\hline & Axis 1 & Axis 2 & Axis 3 & Axis 4 \\
\hline pH & 0.5814 & -0.5307 & -0.147 & 0.003009 \\
Temp (Water Temperature) & 0.6945 & -0.3729 & -0.4537 & 0.1335 \\
Cond (Electrical Conductivity) & 0.4849 & 0.6564 & 0.3081 & 0.3735 \\
Turbz (Turbidity) & 0.5744 & -0.4716 & 0.3413 & -0.2601 \\
TDS (Total Dissolved Solids) & 0.7909 & -0.1442 & 0.1959 & 0.4926 \\
N (Total Nitrogen) & 0.3002 & 0.6891 & -0.5606 & 0.01534 \\
P (Total Phosphorus) & 0.5842 & 0.5378 & 0.265 & -0.368 \\
DO (Dissolved Oxygen) & -0.7713 & -0.1466 & 0.1119 & 0.396 \\
\hline
\end{tabular}

Table 3. Results of Lamparelli's trophic state analysis (CETESB, 2015) based on the total phosphorus concentration and the trophic state index (TSI) (average among samples by site).

\begin{tabular}{|lcc|}
\hline \multicolumn{1}{c|}{ Trophic State } & $\begin{array}{c}\text { Total Phosphorus } \\
\left(\mathbf{m g} \cdot \mathbf{m}^{-3}\right)\end{array}$ & Trophic State Index (TSI) \\
\hline P1: Supereutrophic & 82 & 69 \\
\hline P2: Hypereutrophic & 166 & 73 \\
\hline P3: Supereutrophic & 71 & 68 \\
\hline
\end{tabular}

Trophic state analysis criterion (CETESB, 2015)

Trophic state

Value for weighting (by arithmetic average)
Total Phosphorus $\left(\mathrm{mg} \cdot \mathrm{m}^{-3}\right)$

Trophic State Index (TSI) criterion for

total phosphorus

TSI (TP) $=10^{*}$

(6-(1.77-0.42* $(\ln T P) / \ln 2))$

In = natural

logarithm $=\log _{\mathrm{e}}$ and TP $=$ Total Phosphorus

\begin{tabular}{cccc}
\hline Ultra-oligotrophic & 0.5 & TP $\leq 8$ & TSI $\leq 47$ \\
\hline Oligotrophic & 1 & $8<$ TP $\leq 19$ & $47<$ TSI $\leq 52$ \\
\hline Mesotrophic & 2 & $19<$ TP $\leq 52$ & $47<$ TSI $\leq 52$ \\
\hline Eutrophic & 3 & $52<$ TP $\leq 120$ & $59<$ TSI $\leq 63$ \\
\hline Supereutrophic & 4 & $120<$ TP $\leq 233$ & $63<\mathrm{TSI} \leq 67$ \\
\hline Hypereutrophic & 5 & $233<\mathrm{TP}$ & $67<\mathrm{TSI}$ \\
\hline
\end{tabular}

P1 -Taquacetuba, P2 - Alvarenga and P3 - Biguás Island at Billings Reservoir (Brazil, São Paulo State).

sites: P1 (69), P2 (73) and P3 (68). The assessment using the average of the weighted scores of the results obtained for the total phosphorus $\left(\mathrm{mg} \cdot \mathrm{m}^{-3}\right)$ and the trophic state index shows hypereutrophic conditions at P2 and supereutrophic conditions at the other sites.

\subsection{Benthic macroinvertebrates community and biotic indices}

The analysis of relative abundance (Figure 4) that was conducted by adding up all samples by site showed a greater presence of Oligochaeta at P2 compared to P1 and P3. Chaoborus sp. showed a great abundance at all sites. Chironomini was also observed at all sites and showed higher abundances at P3 and P1. Polymitarcyidae showed a higher abundance at P1.
CETESB (2013) classifies some taxa of the zoobenthos by their tolerance/sensitivity to different environmental impacts. According to this classification, the sensitive group (Polymitarcyidae) was more abundant at P1 (23.27\%) compared to the other sites, where it was almost absent $(<2.5 \%)$; the semi-tolerant group (Chironomini, Tanypodinae, Ceratopogonidae and Helobdella stagnalis, Linnaeus, $1758)$ was more abundant at P3 $(88.51 \%)$ and P1 (64.43\%) compared to P2 (38.44\%); and the tolerant group (Oligochaeta) was more abundant at P2 (59.86\%) compared to P1 (12.30\%) and P3 (9.20\%).

The distribution of the biotic index values by site (Figure 5) shows a tendency for higher values of total density, Shannon-Weaver diversity, taxa richness and uniformity at $\mathrm{P} 1$ and higher values of Simpson's dominance at P2 and P3. In general, 


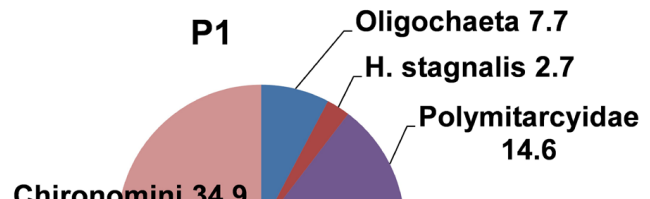

Chironomini 34.9

Chaoborus 37.4

\section{Ceratopogonidae}

Chaoborus 46.1
Chironomini 14.3

Oligochaeta 32.2
P2

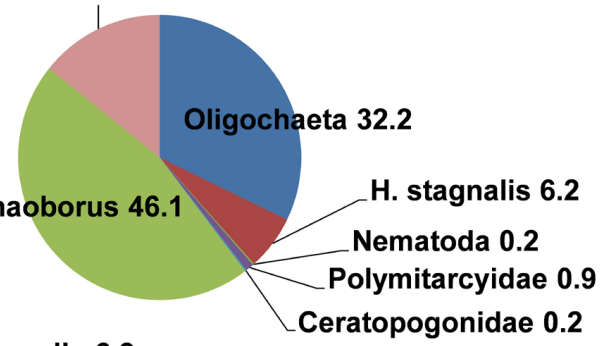

Tanypodinae 2.7

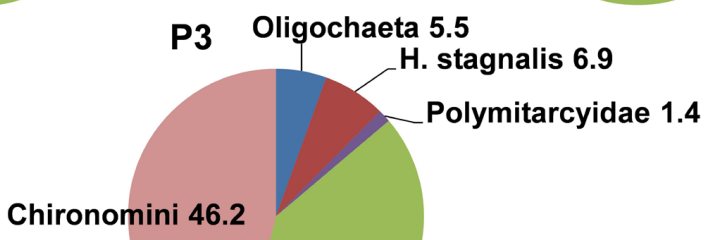

Chaoborus 40.0

Figure 4. Relative abundances (\%) of benthic macroinvertebrates by sampling site (P1 - Taquacetuba, P2 - Alvarenga and P3 - Biguás Island) at Billings Reservoir (Brazil, São Paulo State).
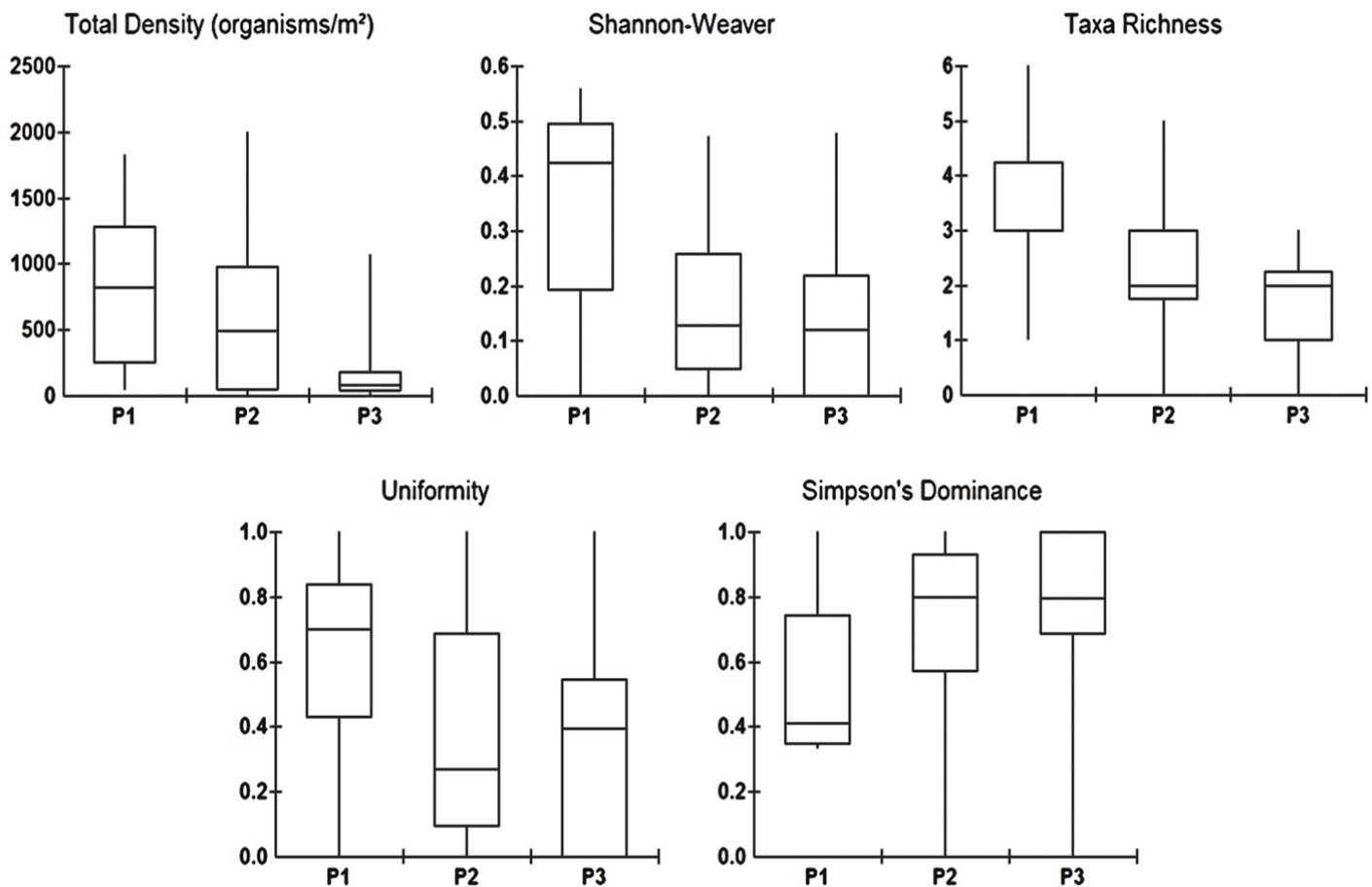

Figure 5. Biotic indices by sampling site (P1 - Taquacetuba, P2 - Alvarenga and P3 - Biguás Island) in Billings Reservoir (Brazil, São Paulo State), represented by box-and-whiskers plots, where the lower and upper limits of the box correspond to the 25 th and 75 th percentiles, respectively, the whiskers correspond to the minimum and maximum, and the center line of distribution corresponds to the median.

all the samples showed low values of total density (lower than $2000 \mathrm{org} \cdot \mathrm{m}^{-2}$ ), Shannon-Weaver diversity (lower than 0.56 ), and taxa richness (lower than 6). The medians of the uniformity values were lower than 0.5 at $\mathrm{P} 2$ and $\mathrm{P} 3$, and the medians of the dominance values were higher than 0.5 at $\mathrm{P} 2$ and $\mathrm{P} 3$.

TheKruskal-Wallistest $(\mathrm{H})$ and aposteriorimultiple comparisons using the Student-Newman-Keuls test (Table 4) show significant differences $(p<0.05)$ for 
the total densities between P1 and P3, the ShannonWeaver diversity between $\mathrm{P} 1$ and $\mathrm{P} 2$ and between $\mathrm{P} 1$ and $\mathrm{P} 3$, and the taxa richness between $\mathrm{P} 1$ and P3. This analysis therefore demonstrates that P1 significantly differs from the other sites.

The multimetric benthic community index, BCI (CETESB, 2013), which is calculated using the Shannon-Weaver diversity and taxa richness values, classified $\mathrm{P} 1$ as regular and the other sites as bad (Table 5).

\subsection{Canonical Correspondence Analysis (CCA)}

The results of the CCA are shown in Figure 6. The first two axes explain $88.82 \%$ of the total variability in the analyzed data. The substantial overlap of the dispersion of the data clouds (convex hull) of the three sites indicates that they have similar conditions in relation to water quality and the composition of the zoobenthos. However, P1 showed better water quality, indicated by its greater association with dissolved oxygen and Polymitarcyidae.

\section{Discussion}

All of the sites sampled in this study are in a high degree of eutrophication and an accelerated process of degradation. The benthic community showed relative abundance values of organisms that are tolerant or semi-tolerant to environmental impacts of higher than $76 \%$ at P1 and higher than $97 \%$ at the other sites, indicating environmental stress and a high degree of eutrophication. The high values of TN and TP, which were in non-compliance with CONAMA (2005) Resolution \#357, also indicated a high degree of eutrophication.

The sensitive taxa of the order Ephemeroptera and family Polymitarcyidae were fifteen times more abundant at P1 than $\mathrm{P} 2$ and ten times more abundant at $\mathrm{P} 1$ than $\mathrm{P} 3$, indicating that $\mathrm{P} 1$ has better environmental conditions, which was corroborated by higher DO values. Most species of Ephemeroptera show a preference for apparently clean water with high concentrations of oxygen (Wetzel, 1993).

Better environmental conditions at P1 were also indicated by the benthic community indices,

Table 4. Results of Kruskal-Wallis test (H) and subsequent Student-Newman-Keuls test (SNK) for biotic indices among the sampling sites.

\begin{tabular}{lccccc}
\hline & \multicolumn{2}{c}{ Kruskal-Wallis } & \multicolumn{2}{c}{ Student-Newman-Keuls } \\
\cline { 2 - 6 } & $\mathbf{H}$ & $\boldsymbol{p}$ & $\begin{array}{c}\text { Sampling sites } \\
\text { compared }\end{array}$ & SNK & $\boldsymbol{p}$ \\
\hline Total Density & $\mathbf{8 . 7 7 3 7}$ & $\mathbf{0 . 0 1 2 4 ^ { * }}$ & $\mathrm{P} 1$ and P3 & $\mathbf{1 2 . 6 2 5}$ & $\mathbf{0 . 0 0 3 3 ^ { * }}$ \\
Shannon-Weaver & $\mathbf{8 . 5 8 4 8}$ & $\mathbf{0 . 0 1 3 7 ^ { * }}$ & $\mathrm{P} 1$ and P2 & $\mathbf{9 . 9 5 8 3}$ & $\mathbf{0 . 0 2 0 6}^{*}$ \\
Taxa Richness & & & $\mathrm{P} 1$ and P3 & $\mathbf{1 1 . 6 6 6 7}$ & $\mathbf{0 . 0 0 6 7}^{*}$ \\
Uniformity & $\mathbf{9 . 5 7 0 6}$ & $\mathbf{0 . 0 1 3 7 ^ { * }}$ & $\mathrm{P} 1$ and P3 & $\mathbf{1 2 . 7 5}$ & $\mathbf{0 . 0 0 3}^{*}$ \\
Simpson's Dominance & 4.5128 & 0.1047 & & & \\
\hline
\end{tabular}

P1 - Taquacetuba, P2 - Alvarenga and P3 - Biguás Island at Billings Reservoir (Brazil, Sáo Paulo State), where * indicates significant difference $(p<0.05)$.

Table 5. Results of the benthic community index (BCI) based on the diversity and richness (average among samples by site).

\begin{tabular}{|c|c|c|c|}
\hline \multicolumn{2}{|c|}{ Benthic Community Index } & Shannon-Weaver & Taxa Richness \\
\hline \multicolumn{2}{|c|}{ P1: REGULAR } & 1.16 & 3.58 \\
\hline \multicolumn{2}{|l|}{ P2: BAD } & 0.53 & 2.33 \\
\hline \multicolumn{2}{|l|}{ P3: BAD } & 0.44 & 1.75 \\
\hline \multicolumn{4}{|c|}{ Benthic Community Index criterion (CETESB, 2013) } \\
\hline Classification & $\begin{array}{c}\text { Value for weighting } \\
\text { (by arithmetic average) }\end{array}$ & Shannon-Weaver (H') & Taxa Richness (S) \\
\hline GREAT & 1 & $H^{\prime}>2.50$ & $S \geq 21$ \\
\hline GOOD & 2 & $2.50 \geq H^{\prime}>1.50$ & $20>S>14$ \\
\hline REGULAR & 3 & $1.50 \geq H^{\prime}>1.00$ & $6>S>13$ \\
\hline BAD & 4 & $1.0 \geq \mathrm{H}^{\prime}$ & $5 \geq S$ \\
\hline
\end{tabular}

P1 - Taquacetuba, P2 - Alvarenga and P3 - Biguás Island at Billings Reservoir (Brazil, Sáo Paulo State). 


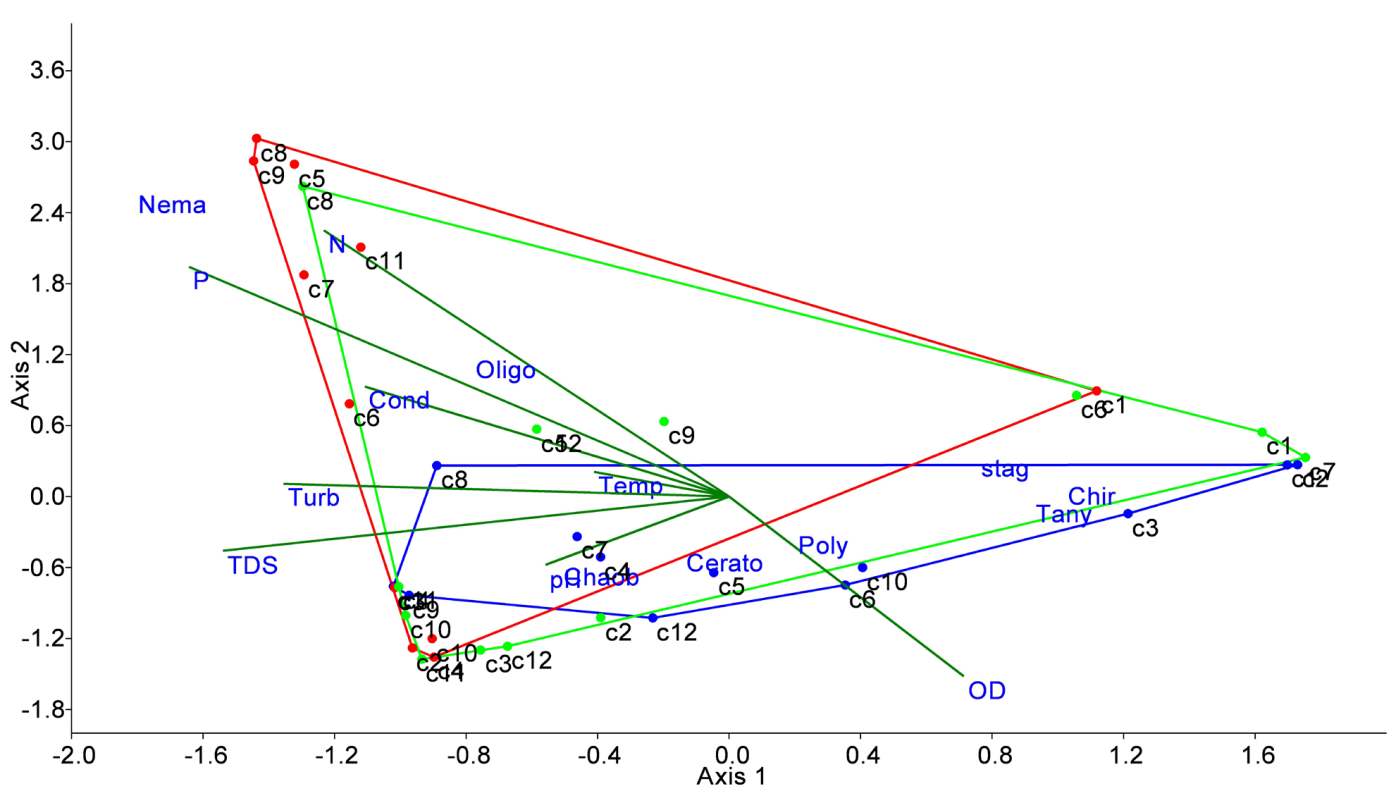

Figure 6. Results of canonical correspondence analysis (CCA) to verify the ordering of the sampling sites in relation to the intensity of the association among the abiotic and biotic variables. The numbers represent the collections (samples): C1 (17.04.12), C2 (22.05.12), C3 (26.06.12), C4 (26.06.12), C5 (13.09.12), C6 (24.09.12), C7 (06.11.12), C8 (04.12.12), C9 (18.12.12), C10 (17.01.13), C11 (05.03.13) and C12 (26.03.13). The lines (convex hull) indicate the cloud (data points) represented by the measurements at each site: P1 - Taquacetuba (blue), P2 - Alvarenga (red) and P3 - Biguás Island (green) in Billings Reservoir (Brazil, São Paulo State). The vectors (dark green) show the contributions of the variables $\mathrm{pH}$, temperature (Temp), electrical conductivity (Cond), turbidity (Turbz), total dissolved solids (TDS), total nitrogen (N), total phosphorus (P) and dissolved oxygen (DO), and the Chironomini (Chir), Tanypodinae (Tany), Chaoborus (Chao), Ceratopogonidae (Cerato), Polymitarcyidae (Poly), Nematoda (Nema), Helobdella stagnalis (stag) and Oligochaeta (Oligo) in the formation of the axes.

which showed higher values of Shannon-Weaver diversity and taxa richness at this site. This analysis is corroborated by the results of the multimetric benthic community index (BCI), which classified $\mathrm{P} 1$ as regular and the other sites as bad.

The relative abundance of Oligochaeta at P2 was four times higher than at the other sites; these organisms are very resistant and are able to survive under oxygen depletion (Heller \& Ehrlich, 1995), being associated with eutrophic water (Lang, 1990), again indicating the poor environmental conditions at this site. In a study carried out by Pamplin et al. (2006) at Americana Reservoir, which shows hypereutrophic characteristics, $73 \%$ of the invertebrates collected were oligochaetes.

The abiotic variables confirm the worst water quality at P2, the site with the most accelerated eutrophication. This site had significantly higher values of electrical conductivity, total phosphorus and lower dissolved oxygen concentrations than the other sites and was the only site with dissolved oxygen values in non-compliance with current legislation in Brazil (CONAMA, 2005, \#357). Cardoso-Silva et al. (2014) found values of electrical conductivity close to those found in this study at Taquacetuba and higher values at Pedreira, a location near Alvarenga and under the influence of the pumping of the Pinheiros River. The same author found values of DO in non-compliance with current legislation in Brazil at Pedreira, showing the worst conditions at sites under the influence of the pumping of the Pinheiros River.

The PCA showed that P2 had a greater association with abiotic variables indicative of environmental stress, and the trophic state index indicated a high degree of eutrophication at all sites with worse conditions at P2 (hypereutrophic) compared to the other sites (supereutrophic). Various authors associate the worst conditions at Alvarenga to deficiencies in sewage collection (Moschini-Carlos et al., 2009; Cardoso-Silva et al., 2014).

The study of Hortellani et al. (2012), conducted at Billings Reservoir fishing sites, corroborates this 
study, demonstrating that the Billings Reservoir has a high degree of degradation with accelerated eutrophication conditions in addition to being contaminated by metals in sediment. Alvarenga proved to be the site with the highest degree of eutrophication and higher metal contamination in sediment, which directly reflects the quality of the water and fish. Hortellani et al. (2012) mention that Alvarenga is a critical area for the accumulation of metals in sediment and also that a slight increase in mercury at Taquacetuba and Biguás Island occurs during the rainy period.

The abiotic assessment differentiated Alvarenga (P2) from the other sites, showing that this site had the highest degradation of water quality compared to the other sampled sites. On the other hand, the macroinvertebrate analyses improved the assessment of the water quality, setting apart the sites with higher values of dissolved oxygen, especially Taquacetuba (P1), where sensitive taxa occurred. Therefore, in conclusion, the benthic community in association with abiotic metrics proved to be a useful tool as an indicator of environmental conditions. The results indicated that the fishing activity at Billings Reservoir must be done with caution at the three sampling sites, but fishing is especially not recommended at Alvarenga due to the worst water quality occurring at this site, as shown by the values of the abiotic variables, the TSI, and the higher abundance of tolerant organisms.

\section{Acknowledgements}

We thank EMAE (Empresa Metropolitana de Águas e Energia S.A.) for the availability of information and the Billings Reservoir fishing community (Capatazia Z1 of São Bernardo do Campo) for its support and availability of information.

\section{References}

ASSEMBLEIA LEGISLATIVA DO ESTADO DE SÃO PAULO - ALESP. Decreto no. 10755 de 22 de novembro de 1977. Dispóe sobre o enquadramento dos corpos de água receptores na classificaçáo prevista no Decreto no. 8468 1976, e dá providências correlatas. Diário Oficial da Uniāo (da) República Federativa do Brasil, Brasília, DF, 22 nov. 1977.

BEGON, M., TOWNSEND, C.R. and HARPER, J.L. Ecologia: de individuos a ecossistemas. Porto Alegre: Artmed, 2007.

BRANDIMARTE, A.L. and ANAYA, M. MethodsBottom fauna flotation using a solution of sodium chloride. Verhandlungen des Internationalen Verein Limnologie, 1998, 26(5), 2358-2359.
BUSS, D.F. and VITORINO, A.S. Rapid Bioassessment Protocols using benthic macroinvertebrates in Brazil: evaluation of taxonomic sufficiency. Journal of the North American Benthological Society, 2010, 29(2), 562-571. http://dx.doi.org/10.1899/09-095.1.

BUSS, D.F., OLIVEIRA, E.B. and BAPTISTA, D.F. Monitoramento biológico de ecossistemas aquáticos continentais. Oecologia Brasiliensis, 2008, 12(3), 339-345.

CALLISTO, M., ESTEVES, F.A., GONÇALVES JUNIOR, J.F. and FONSECA, J.J.L. Benthic macroinvertebrates as indicators of ecological fragility of small rivers (igarapés) in a bauxite mining region of Brazilian Amazonia. Amazoniana, 1998, 15(1/2), 1-9.

CARDOSO-SILVA, S., NISHIMURA, P.Y., PADIAL, P.R., MARIANI, C.F., MOSCHINI-CARLOS, V. and POMPÊO, M.L.M. Compartmentalization and water quality: Billings Reservoir case. Bioikos, 2014, 28(1), 31-43.

CAREW, M.E., PETTIGROVE, V., COX, R.L. and HOFFMANN, A.A. The response of Chironomidae to sediment pollution and other environmental characteristics in urban wetlands. Freshwater Biology, 2007, 52(12), 2444-2462. http://dx.doi. org/10.1111/j.1365-2427.2007.01840.x.

CASTRO, P.M.G., MARUYAMA, L.S., ALVES-DASILVA, M E.P. and PAIVA, P. Produção pesqueira do Reservatório Billings (Alto Tietê - SP) nos anos de 2005, 2006 e 2007. São Paulo: Boletim do Instituto de Pesca, 2009, 10 p. Série Relatórios Técnicos do Instituto de Pesca, no. 38.

COMPANHIA AMBIENTAL DO ESTADO DE SÃO PAULO - CETESB. Qualidade das águas superficiais no Estado de São Paulo 2012. São Paulo: CETESB, 2012, 370 p.

COMPANHIA AMBIENTAL DO ESTADO DE SÃO PAULO - CETESB. Qualidade das águas superficiais no Estado de São Paulo 2013. São Paulo: CETESB, 2013, 434 p.

COMPANHIA AMBIENTAL DO ESTADO DE SÃO PAULO - CETESB. IET - Índice do Estado Trófico: apêndice C: indices de qualidade das águas. São Paulo: CETESB, 2015, pp. 10-12. Relatório de Qualidade das Águas Superficiais do Estado de São Paulo, 2015

CONSELHO NACIONAL DO MEIO AMBIENTE - CONAMA. Resolução no 357 de 17 de março de 2005. Dispóe sobre a classificação dos corpos de água e diretrizes ambientais para o seu enquadramento, bem como estabelece as condiçóes e padróes de lançamento de efluentes, e dá outras providências. Diário Oficial da Uniāo (da) República Federativa do Brasil, Brasília, DF, 18 mar. 2005.

CORTELEZZI, A., PAGGI, A.C., RODRÍGUEZ, M. and CAPITULO, A.R. Taxonomic and nontaxonomic responses to ecological changes in an urban lowland stream through the use of Chironomidae (Diptera) 
larvae. The Science of the Total Environment, 2011, 409(7), 1344-1350. PMid:21276601. http://dx.doi. org/10.1016/j.scitotenv.2011.01.002.

ELLIOTT, J.M. Statistical analysis of samples of benthic invertebrates. Ambleside: Freshwater Biological Association, 1977, 157 p.

EMPRESA METROPOLITANA DE ÁGUAS E ENERGIA S.A. - EMAE. Dados diários de bombeamento de transposição da água do rio Pinheiros para o reservatório Billings (SP) no controle de cheias compartimento Pedreira. Departamento de Supervisão de Operaçóes, 2014.

FONSECA-GESSNER, A.A. and GUERESCHI, R.M. Macroinvertebrados bentônicos na avaliação da qualidade da água de três córregos na Estação Ecológica de Jataí, Luiz Antonio, SP, Brasil. In J.E. SANTOS and J.S.R. PIRES, eds. Estudos Integrados em ecossistemas: estação Ecológica de Jataí. São Carlos: Rima, 2000, vol. 2, pp. 707-731.

HAIR, J.F., BLACK, W.C., BABIN, B.J. and ANDERSON, R.E. Multivariate data analysis. 7th ed. Upper Saddle River: Pearson Prentice Hall, 2009.

HELLAWELL, J.M. Biological indicators of freshwater pollution and environmental management. New York: Elsevier Science, 1986, 546 p. http://dx.doi. org/10.1007/978-94-009-4315-5.

HELLER, J. and EHRLICH, S. A freshwater Prosobranch, Melanoides tuberculata, in a hydrogensulfide stream. Journal of Conchology, 1995, 35, 237-241.

HORTELLANI, M.A., SARKIS, J.E.S., MENEZES, L.C.B., BAZANTE-YAMAGUISHI, R., PEREIRA, A.S.A., GARCIA, P.F.G., MARUYAMA, L.S. and CASTRO, P.M.G. Assessmentof metal concentration in the Billings Reservoirsediments, São Paulo State, southeastern Brazil. Journal of the Brazilian Chemical Society, 2012, 00(00), 1-10.

JORCIN, A. and NOGUEIRA, M.G. Benthic macroinvertebrates in the Paranapanema Reservoir cascade (southeast Brazil). Brazilian Journal of Biology = Revista Brasileira de Biologia, 2008, 68(4, Suppl), 1013-1024. PMid:19197472. http://dx.doi. org/10.1590/S1519-69842008000500009.

KARR, J.R. Defining and measuring river health. Freshwater Biology, 1999, 41(2), 221-234. http:// dx.doi.org/10.1046/j.1365-2427.1999.00427.x.

LANG, C. Quantitative relationship between oligochaete communities and phosphorus concentrations in lakes. Freshwater Biology, 1990, 24(2), 327-334. http://dx.doi.org/10.1111/j.1365-2427.1990. tb00713.x.

LEAL, J.J.F. and ESTEVES, F.A. Density and biomass of Campsurus sp. (Ephemeroptera) and other macroinvertebrates in an Amazonian lake impacted by bauxite tailings (Lago Batata, Pará, Brazil). Amazoniana, 1999, 15(3/4), 193-209.
LINKE, S., NORRIS, R.H., FAITH, D.P. and STOCKWELL, D. ANNA: a new presiction method for bioassessment programs. Freshwater Biology, 2005, 50(1), 147-158. http://dx.doi.org/10.1111/j.13652427.2004.01286.x.

MACAN, T.T. Invertebrados de agua dulce: guia de animales. Pamplona: EUSA, 1975, 118 p.

MACKERETH, F.J.H., HERON, J. and TALLING, J.F. Water analysis: some revised methods for limnologists. Kendall: Titus Wilson \& Son Ltd, 1978, 117 p. Freshwater Biological Association Scientific Publication, no. 36.

MERRITT, R.W. and CUMMINS, K.W., eds. An introduction to the aquatic insects of North America. Iowa: Kendall/Hunt Publishing Company, 1995.

MISERENDINO, M.L., CASAUX, R., ARCHANGELSKY, M., DI PRINZIO, C.Y., BRAND, C. and KUTSCHKER, A.M. Assessing land-use effects on water quality, in-stream habitat, riparian ecosystems and biodiversity in Patagonian northwest streams. The Science of the Total Environment, 2011, 409(3), 612-624. PMid:21094515. http://dx.doi.org/10.1016/j. scitotenv.2010.10.034

MORENO, P. and CALLISTO, M. Bioindicadores de qualidade de água ao longo da Bacia do Rio das Velhas [online]. 2005 [viewed 01 July 2015]. Available from: http://150.164.90.128/assets/files/Biblioteca_ Virtual/MorenoeCallisto-202005-EMBRAPA.pdf

MOSCHINI-CARLOS, V., PINTO, E., NISHIMURA, P.Y., FREITAS, L.G., POMPÊO, M.L.M. and DORR, F. Analisys of water quality in the Billings and Guarapiranga Reservoir (SP, Brazil): Emphasis on cyanobacteria and cyanotoxins. Limnética, 2009, 28, 273-282.

PAMPLIN, P.A.Z., ALMEIDA, T.C.M. and ROCHA, O. Composition and distribution of benthic macroinvertebrates in Americana Reservoir (SP, Brazil). Acta Limnologica Brasiliensia, 2006, 18, 121-132.

PENNAK, R.W. Freshwater invertebrates of United States: protozoa to mollusca. 3rd ed. Hoboken: WileyInterscience, 1991, $628 \mathrm{p}$.

PÉREZ, G.R. Guía para el estudio de los macroinvertebrados acuáticos del Departamento de Antioquia. Bogotá: Presencia, 1996, 217 p.

RICKLEFS, R.E. A economia da natureza. 6th ed. Rio de Janeiro: Guanabara/Koogan, 2011, 546 p.

ROSENBERG, D.M. and RESH, V.H., eds. Freshwater biomonitoring and benthic macroinvertebrates. New York: Chapman \& Hall, 1993, 487 p.

SILVA, M.E.P.A., CASTRO, P.M.G., MARUYAMA, L.S. and PAIVA, P. Levantamento da pesca e perfil socioeconômico dos pescadores artesanais profissionais no reservatório Billings. Boletim do Instituto de Pesca, Sao Paulo, 2009, 35(4), 531-543. 
SOKAL, R.R. and ROHLF, F.J. Introduction to biostatistics. 2nd ed. New York: Dover Publications, 2009, 363 p.

STRICKLAND, J.D. and PARSONS, T.R. A manual of sea water analysis. 2nd ed. Ottawa: Bulletin Fisheries Research Board, 1960, vol. 125, pp. 1-185.

TRIVINHO-STRIXINO, S. and STRIXINO, G. Larvas de Chironomidae (Diptera) do Estado de São Paulo: guia de identificação e diagnose dos gêneros. São Carlos: PPG-ERN/UFSCar, 1995, 229 p.
VALDERRAMA, J.C. The simultaneous analysis of total nitrogen and total phosphorus in natural waters. Marine Chemistry, 1981, 10(2), 109-122. http:// dx.doi.org/10.1016/0304-4203(81)90027-X.

WETZEL, R.G. Limnologia. Lisboa: Fundaçẫo Calouste Gulbenkian, 1993, 1010 p.

ZAR, J.H. Biostatistical analysis. 5th ed. Hoboken: Pearson Prentice Hall, 2010.

Received: 15 September 2015

Accepted: 23 September 2016 